\title{
Könyvszemle
}

Nagy Beáta (szerk.):

Klinikai gyermeklélektan és preventív egészségpszichológia a gyakorlatban

(Clinical child psychology and preventive health psychology in practice)

Debreceni Egyetem, Debrecen, 2014

404 oldal, $3000 \mathrm{Ft}$

ISBN: 978-963-473-726-1

A kötet szerkesztóje korábban a klinikai gyermekpszichológia szép, de küzdelmes eseteit bemutató szöveggyújteménnyel jelentkezett. A jelen munkában 11 empirikus kutatást olvashatunk, amelyek zömében a gyermek- és serdülókorú populáció körében egyre gyakoribbá váló krónikus megbetegedésekre fókuszálnak, de találunk a felnôttek életét érintô kérdéseket is. A növekvô tendencia az egészségügyi, az oktatási, valamint a szociális ellátórendszer múködését is befolyásolja, jelezve ezzel a kutatások népegészségügyi jelentóségét. A klinikai gyermeklélektan és a preventív egészségpszichológia szemléletét ötvözve kívánnak rámutatni az írások azon gyakorlati szempontokra, amelyek mind a megelózésben, mind a kezelésben egyaránt hasznosíthatók.

A szerkesztó, Dr. Nagy Beáta PhD, egyetemi docens, klinikai szakpszichológus, pszichoterapeuta, a Debreceni Egyetem, Klinikai Központ Népegészségügyi Karán múködô Magatartástudományi Intézet, Klinikai és Egészségpszichológiai Tanszék oktatója. Több mint harminc éve foglalkozik leginkább a koraszülöttségból fakadó, krónikus betegségben szenvedó gyermekek vizsgálatával, gyógyításával szakrendelést vezetve; valamint számos, a gyermekrehabilitáció területéról származó tudományos cikk, illetve könyv írója.

A kötet sorban a gyermek-, valamint a serdülókorú populáció körében végzett vizsgálati anyagokat, valamint az ehhez kapcsolódó elméleti hátteret mutatja be magyar, illetve angol nyelvú szakirodalomra támaszkodva.

Az asztma, az obezitás, valamint a bórgyógyászati betegségek témáját felöleló kutatások jelentôsége nagy. A gyermekek körében ezen betegségek növekvố tendenciája egyre alaposabb ismereteket, valamint hatékony meg- 
oldásmódokat kíván. A betegségteher és az életminóség tekintetében megállapítást nyert, hogy a gyermekek - bár különbözó mértékben - rossznak ítélik életminôségüket, pesszimizmusra való hajlamuk pedig rontja a betegségükkel való megküzdés sikerességét. A gyógyulás szempontjából a pszichés támogatás az érzelmi állapot javítását kell, hogy célozza, állítja a kutatás. Fontos odafigyelni a családi kapcsolatokra, fóleg az anya-gyerek kapcsolat ápolására, leginkább az asztmás gyermekek tekintetében. A túlsúly leküzdése esetében a testmozgás jelentósége nô meg. A gyógyulás sikeressége szempontjából a szülók, az orvosok, valamint a tanárok ismereteinek pontosítása is szükséges, valamint a gyermekekkel kapcsolatos különféle attitúdök egységesítése, a betegséggel kapcsolatos tudatosság növelése.

A genetikai rendellenességben szenvedó, valamint az onkológiai problémával küzdő gyermekek szüleivel folytatott interjúk narratív szempontú elemzése rámutatott arra, hogy a megküzdés során a környezet pszichológiai, emocionális és egzisztenciális nehézségekkel egyaránt szembenéz. A gyermek kezelése jelentős többletköltséggel jár, miközben a szülóknek a munkahely elvesztésének lehetséges tényével is szembe kell nézniük. Az eredmények zöme a szakirodalom adatait támasztja alá. A teljes családokra kiterjedó vizsgálat a beteg gyermek állapotának tartós lefolyása tekintetében mindkét betegségcsoportnál a családi kohézió növekedését és csökkenését találta. Emellett jellemző, hogy az egészséges testvér az állapot pozitív és negatív vonatkozásait egyaránt megéli.

A diagnózissal való szembesülés, az állapot okának keresése, valamint a megküzdés miatti tehetetlenségérzés és a jövő kilátástalansága vonatkozásában nem mutatkozik eltérés a két csoport esetében. Az idóbeli lefutás és a lehetséges kimenetelek tekintetében a genetikai rendellenességben érintett gyermeket neveló családokban nagyobb gyakorisággal fordulnak elô pozitív emocionális állapotra utaló tartalmak. Ebben az esetben már a születéstól elindul az állapot elfogadásának folyamata, míg az onkológiai betegség esetében a gyermek lehetséges elvesztésének ténye, ennek elfogadása súlyos teherként nehezedik a családra, nem említve a váratlan helyzetek kezelését. Túlvédô szülôi attitúd inkább az onkológiai csoportban jelenik meg, a genetikai csoportban a szülóket inkább a gyermek elutasítása miatti belsố konfliktus jellemzi. A család külsố viszonyulása tekintetében a sérült gyermekek szülei gyakrabban számolnak be a gyermek diszkriminációjáról, míg az onkológiai betegséggel küzdó gyermekekre ez kevésbé jellemzó. A kutatás emellett rámutat arra, hogy a gyógyulási esélyek nagymértékben növelhetốk a szakemberek szemléletének szélesítésével, amely a viszonyulásban megjelenố elóítéleteket is csökkentheti.

A veleszületett látássérüléssel élő gyermekek esetében bizonyítást nyert az, hogy látó társaikhoz képest globálisan negatívabb énképpel rendelkeznek 
mind a fogyatékosságukra, mind pedig az iskolai teljesítményükre nézve. Mindez alacsonyabb önértékeléssel is jár. A látássérült gyermekek egészségüket is rosszabbnak ítélik. Ezek kivédésén túl a pszichológus segítsége a környezet stigmatizáló szerepét lenne hivatott enyhíteni.

A magatartászavarral küzdô gyermekek nevelése a családban és az iskolában egyaránt problémát jelent. Beilleszkedésüket megnehezíti az alacsony impulzuskontroll és a szinkronképesség gyengesége, amely azt jelenti, hogy a gyermekek kapacitása alacsony a környezeti változásokkal való együtt vibrálásra. Ugyanez jellemzó az autoagresszív gyermekekre is, akiknek érzelmi és impulzuskontrollja szintén eltér az egészséges populációéhoz képest. A kezelésben így hangsúlyos a megküzdési stratégia fejlesztése, valamint a pszichológiai immunrendszer erósítése. A kutatás kiemeli, hogy a megelózés szempontjából elengedhetetlen a kockázati tényezók csökkentése, mint amilyen az elhanyagolás és a családon belüli erószak. A gyógyszeres kezelés mellett az egyéni, valamint a csoportos terápiák jöhetnek szóba. A szuicidium megelózésében az időfaktor a döntő fontosságú. Sokszor nem áll rendelkezésre megfeleló idói keret az öngyilkossági szándék felismerésére és kezelésére. Leginkább az egészségügynek van kiemelkedố szerepe, de a kutatás javaslatai szerint különbözó centrumok, valamint telefonos szolgálatok megszervezése is segítheti a probléma megoldását.

A serdülók korosztályt tekintve a krónikus betegség, mint a daganatos betegség és a lisztérzékenység kezelése szintén jelentốs érzelmi megterheléssel jár. A vizsgálat rámutatott arra, hogy minél negatívabbnak ítélik a betegségüket a serdülók, annál alacsonyabbnak értékelik az életminóségüket. A segítés területén tehát minél több olyan információt kell biztosítani a családoknak és a gyerekeknek is betegségükkel kapcsolatban, amely a személyes kontroll növekedését eredményezi, azt az érzést, hogy betegségük gyógyítható. Emellett a kezelés folyamatában hatékony lehetne a betegségról kialakított kép monitorozása és annak megváltoztatását célzó programok kidolgozása a kutatás javaslata alapján.

Népszerú témát ölel fel a serdülő populáció kötôdés- és evészavara közötti összefüggések vizsgálata, amely megerósítette, hogy a két zavar között minóségi kapcsolat áll fent, valamint a kóros evési attitúdök és a patológiás kötődési stílusok között erốs az összefüggés. Az alacsony kockázathoz biztonságos kötôdési stílus, a magas kockázati tartományban lányok esetében ambivalens kötődési stílus, fiúk esetében elkerüló/szorongó kötôdési stílus igazolódott. Az eredmények arra mutattak rá, hogy a serdüló korcsoporton belül fóleg a lányok veszélyeztetettek, a fiúknál alacsonyabb a kockázati hajlam az evészavar tekintetében. A kötôdési, valamint az evészavarok kialakulásában a családi kapcsolatrendszer, a múködés minôségé- 
nek kérdése vetôdik fel, ahol a gondoskodás, az igazi kötelékek, valamint a valódi beszélgetések értéke helyezhetó elótérbe.

A serdülók egészségmagatartásának megismerése, valamint az azt befolyásoló tényezók ismerete a további intervenciók megtervezése céljából fontos. Egy következó kutatás a családban éló serdülók esetében a szülói magatartás megfelelő irányba történó formálását hangsúlyozza. Leginkább az anya elfogadó viselkedése igazolódik, mint szignifikáns védófaktor, de az apa érzelmi melegsége sem elhanyagolandó. Mindez erósíti az élet értelmességébe vetett hitet, amely a serdülókori szerfogyasztás és dohányzás védófaktora. A vizsgálat meglepó eredményre mutatott rá, miszerint a határozott életcélok mellett magasabb dohányzási arány és kevesebb fizikai aktivitás jelenik meg. Bizonyítható, hogy a többet sportoló fiatalok körében kisebb a szerfogyasztás elófordulása. Az egészségmagatartási mintázatokat vizsgálva a drogfogyasztás az alkoholfogyasztással gyakran együtt jár, míg a dohányzással nem. A fiúk és a lányok között különbség mutatható ki a fiúk javára a sportolási szokások, valamint az alkoholfogyasztás tekintetében. A konfliktuskezelés és az egészségmagatartás vonatkozásában számottevő összefüggés nem igazolódott.

Árnyalja a képet mindaz, amikor a serdülók egészségmagatartását abban a tekintetben vizsgálják, hogy a serdüló nem családban nevelkedik, hanem állami gondozásba kerül. Ebben az esetben a család támogatása hiányzik, biztonságos, hosszú távú kötôdés kialakulására kevés lehetőség van. Mindez érzelmi és mentális deficitet eredményezhet. Nem alakul ki megfelelő viszonyulás a környezethez. A nem adaptív viselkedésmintázat pedig az egészségmagatartásra és a stressz kezelésére nézve is kockázatos. A vizsgálati eredmények a haza és külföldi tanulmányokat erósítik meg. Az állami gondozottak lelki egészsége, szubjektív jólléte kedvezótlenebb, mint a családban nevelkedóké. Beigazolódott, hogy az állami gondozásban élók, leginkább a fiúk hajlamosabbak a rizikómagatartásra, többet és nagyobb mennyiségben dohányoznak, fiatalabb korban próbálják ki az alkoholt és részegednek le, mint a családban élók. Hangulatuk depresszívebb, önértékelésük és élettel való elégedettségük alulmarad. Alapvetóen az állami gondozott fiúk és lányok korábban kezdenek kockázatkeresó viselkedéssel élni, hamarabb találkoznak a cigarettával és az alkohollal, mint a családban élók. Mindez megerósíti azt, hogy mennyire fontos a lakásotthonban a nevelókkel, gondozókkal való kapcsolat elmélyítése. A szeretetteljes légkör javít az önértékelésen, a biztonság érzete pedig védófaktor a depresszióval szemben.

Egy további kutatás célul túzte ki a gyulladásos bélbetegek életminőségének vizsgálatát. A téma választását indokolja az a tény, hogy a krónikus gyulladásos bélbetegségben (IBD) szenvedó felnótt betegek száma növekszik. 
Komplex, bio-pszicho-szociális szemléletben nézve a szomatikus tüneteken, valamint az anyagi problémákon túl a pszichés tényezók vizsgálata rámutathat, megoldásmódokat adhat a kezelés tekintetében. Ebben a betegek életminósége kulcsfontosságú. A vizsgálati eredmények igazolták azt a feltevést, hogy a bélbetegségben szenvedók szubjektív jólléte alacsonyabb az egészséges populációhoz, illetve más krónikus betegségben (asztma) szenvedókhöz képest. Betegségük nagyobb nyomással nehezedik rájuk, amely az élet minden területére kiterjedô minóségromlással jár. Ez leginkább az interperszonális kapcsolatrendszert, a párkapcsolatot, valamint az intimitást érinti. A kutatás rámutatott a biológiai terápia fontosságára, amely az egyéb kezelési módokhoz képest életminóség-javulást eredményez. A szerzók javaslatot tesznek a klinikai gyakorlatban a terápiás team pszichológussal történó bôvítésére, a betegek életminőségének folyamatos nyomon követésére, amelyben a szubjektív jóllét növelése csökkenti a betegség pszichés terheit, ezáltal növekedhet a terápiák hatékonysága, amely tovább erósítheti az életminóséget.

A népesség gyarapodása napjainkban igen sarkalatos téma, amely a meddôség kutatásának fontosságát minden tekintetben aláhúzza. Ennek kialakulásában és kezelésében lelki tényezók szerepe igazolható. Az utolsóként bemutatott vizsgálat során az a feltevés nyert bizonyítást, hogy a természetes úton szülóvé válók alapvetően erósebb megküzdési módokkal bírnak, mint a mesterséges megtermékenyítésen (in vitro fertilizatio, IVF) átesettek. A nemek tekintetében a férfiak megküzdési potenciái alacsonyabbnak bizonyulnak, míg a nók jobban törekednek az érzelmi egyensúly keresésére, jobban jellemzi óket egyfajta érzelmi és mentális távolságtartás, amely a teherbeesés valószínúségét növelheti. A nók stresszhelyzetben jobban keresik a társas támaszt, fogadják mások együttérzését és megértését. Ugyanakkor az IVF által szülóvé vált párok pszichológiai immunrendszere bizonyíthatóan két területen mutat nagyobb hatékonyságot, miszerint a velük kapcsolatos történések összefüggéseit jobban megértik, kihívásként kezelik, valamint személyiségük jellegzetességeit jobban felismerik, elfogadják. Továbbá ezen párok a késóbbiekben demokratikusabb légkörben nevelik a gyermeküket, mint a természetes úton szülóvé vált párok. Erósebb kontrollt tartanak, elfogadóbbak, gyermekükkel több interakciót folytatnak, véleményüket késóbb inkább figyelembe veszik. A kutatás szerint mindez azzal magyarázható, hogy a gyermekre való, nemegyszer hosszú várakozási idố motiválttá, gyermekcentrikusabbá teszi az embereket, akik a szülőszerep minél hatékonyabb elsajátítására törekednek.

Úgy vélem, a kötet hiánypótló abból a szempontból, hogy a kialakult tünetek kezelésén túl olyan egészségpszichológiai megközelítést is ad, amely a népesség egészségfejlesztése és a prevenció tekintetében kínál megoldás- 
módokat. Emellett a pszichés és szomatikus problémák kezelésében a társadalom színtereinek összehangolódását, valamint tudatos együttmúködését emeli ki, a gyermekek és a felnóttek életében egyaránt.

Nem kisebb a jelentôsége mindennek, ha azt a hatást nézzük, miszerint az egészségügyi ellátórendszer napjainkban tapasztalható nagymértékú leterheltségét mindez csökkentheti. A korszerú egészségpszichológiai kutatások eredményeinek felhasználásával pedig a pszichológus a társszakmák hatékony segítóje lehet, megfelelô együttmúködést elérve ezzel.

\author{
Bezgédi Emma \\ E-mail: bezgediemi@gmail.com
}

Ittzés Gábor (szerk.):

Cura mentis - salus populi: Mentálhigiéné a társadalom szolgálatában: Ünnepi kötet Tomcsányi Teodóra 70. születésnapjára

Cura mentis - salus populi: Mental hygiene in the service of society. Jubilee edition for the 70th birthday of Teodóra Tomcsányi

Interdiszciplináris szakkönyvtár 9. Semmelweis Egyetem, Egészségügyi Közszolgálati Kar, Mentálhigiéné Intézet, Budapest, 2013

572 oldal, $3980 \mathrm{Ft}$

ISBN: 978-963-9129-95-5

Hazánk elsố egyetemi mentálhigiéné tanszékének alapítóját, úttörô kutatóját, iskolateremtó egyéniségét, szakmai testületeinek megteremtőjét, Tomcsányi Teodórát Ittzés Gábor méltatja az Elôszóban. Születésnapi köszöntôvel folytatja Semjén Zsolt (miniszterelnök-helyettes), Szél Ágoston (rektor), Török Péter (volt intézetigazgató), valamint Dávid Beáta (jelenlegi intézetigazgató).

Az ünnepelt életútjáról, sokoldalú munkásságáról múvei bibliográfiájából, a Függelékben nyert kép alapján tájékozódhat az olvasó. A nagy terjedelmú kötetben iránytúnek tekintheti a (45 szerzótól származó) 32 (10 német és 22 magyar nyelven írt) tanulmányt befogadó négy nagy tömböt, amelyek címe: Tudomány - Gyakorlat - Oktatás - Kutatás.

A tanulmányok mindegyike valamiképpen illeszkedik Tomcsányi Teodóra múködéséhez. Egyenló figyelmet is érdemelnek, ezt azonban terjedelmi okból nem könnyú érvényesítenem. A szerkesztố bölcsen alakította ki sorrendjüket, célszerú tehát a tartalom szerint haladnunk. A tanulmány címét akkor közlöm külön, ha abból nem túnik ki egyszersmind a témája is. 
A Tudomány tömbje tudománytörténeti érdekességú tanulmányokkal kezdódik.

Patrick Luyten és Jozef Corveleyn (Catholic University of Leuven) a Han Israëls holland szociológus (németre is lefordított) Het geval Freud („A Freud-eset") címú könyvében megfogalmazott, Freud elleni vádaskodások alaptalanságát mutatja ki. Susanne Heine (a bécsi egyetem teológiai fakultásáról) az „Egy illúzió jövője” címú írás kapcsán Freud és barátja, Oskar Pfister protestáns lelkész, valamint Theodor Reik vitájáról ad számot (ez az ösztönökról való lemondásról, az intellektus elsóbbségéról folyt köztük). Grete Leutz (Moreno Institut für Psychodrama, Überlingen) Freud és Moreno idókezelését, múltbeli tapasztalatok újra átélésének jelentôségét veti egybe az átvitel, illetóleg a segédénekhez való szerep-hozzárendelés szempontjából.

A mentálhigiéné elméletéhez járul hozzá Nagy J. Endre a Polányi Mihály: Személyes tudás címú múvéból vett „kitörés” fogalom magyarázatával. A lelki egészség fogalmába a normálistól eltéró emberi szükségletek is beletartozhatnak, megítélésük már elózetes értékválasztást feltételez. Varga Károly a vallás és a lelki egészség kapcsolatával foglalkozik, szembeállítva egymással a spiritualitás és a tudatosság kérdésköre mentén szerveződő modelleket. Patsch Ferenc a mentálhigiénés szemléletben a (vallásfilozófiai álláspontokból eredeztethetô) felsóbbrendúséget valló álláspont meghaladására, a sokszínúség melletti kiállásra buzdít.

A társadalmi mentalitásban jelen lévő spiritualitás az étel (és élet) értékéhez kapcsolódva az evészavarokban is szerepet játszhat - derül ki Túry Ferenc, Lázár Imre, Zsinkó-Szabó Zoltán és Mezei Ágnes dolgozatából. Az aszketizmus, a böjtölés, a test elutasítása vallásos értelmet kaphat, az evés lehet az önkontroll mércéje, de a kontrollvesztés terepe is. Martin Jäggle (Katholisch-Theologische Fakultät, Universität Wien) „vallásérzékeny képzés”-t tart idószerú feladatnak, a „,saját vallás” és az „idegen vallás” kettősségének feloldását. Karl Heinz Ladenhauf (Institut für Pastoraltheologie und Pastoralpsychologie, Universität Graz) meghallván az idók szavát, a keresztény diakónia útját egyengeti.

A Gyakorlat tömbje pszichoterápiával, pszichodrámával és lelkigondozással foglalkozó tanulmányokat tartalmaz.

Perczel Forintos Dóra Kifürkészhetetlen utak címú, didaktikailag kivált értékes tanulmányában megkísérli „bemutatni a lehetséges (és esetleg meglepó) érintkezési pontokat a különböző pszichoterápiás irányzatok között, és rávilágítani a spiritualitás fontosságára". Kérdés-felelet formában halad lépésról lépésre, alapkérdésektól (például a lelki szenvedés csökkentésének céljától), a pszichodinamikus pszichoterápiáktól való különbözőségeken át, a valóság elfogadásán és a felelősség vállalásán át a „tudatos jelenlét”-ig. 
Reinhard T. Krüger (Moreno Institut, Goslar) pszichotikus betegek Moreno-féle zavarspecifikus pszichoterápiáját azzal a felismeréssel gazdagítja, hogy „a terapeutának magának is egy megváltozott, a valóságot túllépó, transzreális magatartást kell felvennie, és többé-kevésbé folyamatosan a páciens hasonmásává kell válnia".

Csáky-Pallavicini Krisztina és Milák Piroska személyiségzavarban szenvedó páciensek egyéni pszichodramatikus pszichoterápiájához ad szempontokat, például interperszonális problémák lejátszása helyett intrapszichés folyamatok fókuszba állítását és megjelenítését pszichodráma-technikákkal.

Az antiszerepjáték önismereti fontosságát hangsúlyozza Török Szabolcs, bemutatva elméleti és módszertani kérdéseit, a morenói kulcsfogalmakkal való kapcsolatát, „egy lehetséges technikai forgatókönyvet”, sớt, egy esetet is.

Sarkady Kamilla a megbocsátás jelentôségét, pszichodramatikus megközelítését dolgozza fel. "Keresd a békét és járj utána!” Jézus a példa: „az ellenségnek is meg kell bocsátani. Ez csak úgy történhet meg, ha még az ellenségnél is nagyobb ellenfelet, önmagunkat is le tudjuk gyózni."

Marlok Zsuzsa oldás és kötés alapélményeivel, az elengedés gyászhoz hasonló veszteségérzésével, az elbocsátás folyamatának elakadásával, a feloldás pszichodráma-technikáival foglalkozik, mindezt esetekkel illusztrálva. "Fel hát szívem: búcsúzz új gyógyulásra!" - idézi Hesse költeményét a tanulmány címeként.

Sallay Viola és Martos Tamás a csoporthelyzetben alkalmazott többgenerációs családszobor technikáját, gyakorlatát, elméletét mutatja be. A bécsi családterápiás intézetból eredeztethetô, a lelkigondozói képzésben is alkalmazott módszert „afféle szobrászokként” csiszolták tovább.

A kötetben a lelkigondozás is méltó helyet kap. A modern kórházi lelkigondozói szemlélet kialakulásáról Tésenyi Timea értekezik. Idôszerúségét a pszichoszomatikus és holisztikus igényú orvoslás erôsödése adja, szemlélete Rogers-i. Németh Dávid a logoterápia lehetóségeivel foglalkozik (Viktor Emil Frankl nyomán): a logoterápia és a Szentírás egybecsengó helyeinek lelkigondozói alkalmazási lehetóségeit mérlegeli. Hermann Steinkamp (Katholisch-Theologische Fakultät, Westfälische Wilhelms-Universität, Münster) az úgynevezett „úffajta tiszteletbeli megbízatás”-sal (azaz társadalmi munkás munkatársként) tanácsadói kompetenciát szerzố csoportok tagjait mutatja be a telefonos lelkigondozás példáján keresztül.

Az Oktatás tömbje pedagógiai tárgyú írásokat tartalmaz, külön is kiemelve a mentálhigiénés szakemberképzést.

Norbert Mette (Fakultät Humanwissenschaften und Theologie, Technische Universität, Dortmund) valláspedagógiai fogantatású írása a kisgyermekkori vallásos nevelés és képzés aktuális feladatait hangsúlyozza, 
Semsey Gábor pedig az iskolai szexuális neveléssel foglalkozik, a világnézetileg semleges kezdeményezések mellett egyháziakat is bemutatva. Gombocz János dolgozatával („Mi, akik közepét keressük, csak szélein járunk") a sportpedagógiát képviseli, értéktudományi szemléletével ellensúlyozva a mai magyar sportpedagógia egyoldalúan pszichometrikus beállítottságát.

Etikai szempontjai keltenek figyelmet Hanneke Meulink-Korf (Protestant Theological University, Amsterdam) „Találkozás: Kezdeményezések lelkipásztorok/teológusok továbbképzésére a Böszörményi-Nagy Iván szellemében folyó posztgraduális, kontextuális, nemzedékeket átfogó lelkigondozó-képzési gyakorlat alapján Hollandiában" címú, nagy ívú munkája iránt. Érdeme, hogy Martin Buber és Emmanuel Levinas filozófiáját sikerül integrálnia a lelkigondozásba.

Andreas Wittrahm (Caritasverband für das Bistum Aachen) írása pszichológiai adalékokkal szolgál segítő foglalkozásúak továbbképzéséhez. Miként írja: „Megérteni valamit az életból, a szeretetból és a hitból." Török Gábor és Joób Máté a Semmelweis Egyetemen kidolgozott mentálhigiénés szemléletú lelkigondozói továbbképzési modellbe nyújt bepillantást.

A Kutatás tömbje módszertant és empíriát foglal magába a pszichológiában, valamint a pszichológia és a szociológia határterületein.

Ehmann Bea azt mutatja be, hogy a természetes nyelvek elemzése milyen lehetôségeket kínál a pszichológiai tartalomelemzés számára. Hámori Eszter a koraszüló-interjú kidolgozását és alkalmazását foglalta tanulmányba. Vargha András és Császár-Nagy Noémi a Rorschach-teszt pszichometriai kvalitásainak növeléséhez járul hozzá. Sipos Kornél szintén pszichometriai munkával tiszteleg egykori tanszéki kollégája előtt, "testnevelési, sporttudományi és egészségtudományi egyetemi hallgatók szorongás-, kiváncsiság-, harag-és depresszió-, valaminténhatékonyság-mutatóinak összehasonlító vizsgálatá"-val. Ittzés Gábor, Béres Orsolya, Sipos B. Bernadett és Pilinszki Attila a Rokeach-értékskála üdvözülés iteméról megállapítja, hogy „önmagában nem alkalmas arra, hogy árnyalt képet rajzoljon egy populáció vallásosságáról”, de átfogó képet tud adni róla. Török Péter és Ittzés András arra keres választ, hogy „Lehet-e szövetség a keresztények és muszlimok között a házasság és család védelmében?". Az iszlám és a kereszténység alapkoncepcióiban vannak hasonlóságok, két nagy értékkutatás (EVS: European Values Study és WVS: World Values Survey) adatbázisának elemzése kiegészíti az elméleti összevetésból nyert megfontolásaikat. Horváth-Szabó Katalin és Dávid Beáta a családi és kortárstámogatás összefüggéseit vizsgálta serdülók körében. Következtetésük, hogy fontos a családi kapcsolatok erôsítése, családi támogatási hiány esetében viszont a családon kívüli közösségek szerepe nó.

Bár a kötetnek nincs tárgy- és névmutatója, anélkül is bízvást megállapíthatjuk, hogy roppant szellemi értéket képvisel. Egységét erósítik a 
munkatársaknak, tanítványoknak a közös munkával, a pályával kapcsolatos személyes emlékei is.

\section{Lốrincz Jenó}

E-mail: lorincz.jeno@med.semmelweis-univ.hu

Kristina Orth-Gomér - Neil Schneiderman - Viola Vaccarino - HansChristian Deter (Eds.):

Psychosocial stress and cardiovascular disease in women. Concepts, findings, future perspectives

(Pszichoszociális stressz és koszorúér-betegségek nók körében. Elméletek, kutatási eredmények és perspektívák)

Springer, Cham, 2015

305 oldal, 107,09 EUR

ISBN: 978-3-319-09240-9

ISBN: 978-3-319-09241-6 (eBook)

A kötet szerkesztói évtizedek óta vezető kutatói a kardiológia pszichoszociális vonatkozásainak, és jól ismertek a magyar magatartásorvoslási szakemberek körében, mivel az elmúlt években többször szerepeltek Budapesten megrendezett nemzetközi szakmai konferenciákon is. Kristina Orth-Gomér régóta kutatja a nók kardiovaszkuláris kockázati tényezóit, s az utóbbi években - kutatásaira alapozva - szívbeteg nók részére stresszcsökkentố csoportos tréninget dolgozott ki. Neil Schneiderman a magatartásorvoslási irányzat egyik meghatározó egyénisége, aki vezető szerepet játszott a kardiológiai pszichoszomatika egyik legjelentősebb - és sok tanulsággal járó - intervenciós kutatásának, az Enhancing Recovery in Coronary Heart Disease (ENRICHD) vizsgálatnak a megvalósításában. Hans-Christian Deter az elmúlt években szintén folytatott kutatásokat a koszorúér-betegek pszichológiai intervenciós lehetôségeivel kapcsolatban. A kötet szerkesztói úttörói voltak azon interdiszciplináris kutatásoknak, amelyek az elmúlt évtizedekben megváltoztatták a koszorúér-betegségekkel és a szívinfarktussal kapcsolatos felfogást, és ráirányították a figyelmet a klinikailag is releváns nemi különbségekre. Lassan változik az a sztereotípia, miszerint a szívinfarktus elsósorban a férfiak betegsége. Megbízható epidemiológiai kutatások alapján ma már nyilvánvaló, hogy a koszorúér-betegség és a szívinfarktus legalább annyira a nók problémája is, s hogy a korábbi kutatások, amelyek ezeket a betegségeket homogénnek, ,"uniszex”-nek tekintették, gyakran elhanyagolták a nemi különbségeket, ami a klinikai gyakorlatban elsôsorban a szívbeteg nók számára jelentett hátrányt. Kiderült, hogy a szívbetegségek 
megjelenésében is vannak nókre specifikus jellemzók: például a stressz kardiomiopátia (Takotsubo-szindróma) elsốsorban az idôsebb nók betegsége - okai egyelóre kevéssé ismertek, de sok megfigyelés támasztja alá összefüggését jelentôs pszichés megterhelésekkel. Egy másik klinikailag fontos nói jellegzetesség a mikrovaszkuláris hátterú akut koronária szindróma, amely a rutin koronarográfiával nem kimutatható.

A kötet nagy hangsúlyt fektet a nemi különbségeket magyarázó stresszel összefüggő biopszichológiai és kórélettani mechanizmusokra. A legkézenfekvóbb magyarázat - a nemi hormonok szerepe - mellett, összefoglalást kapunk a gyulladásos, illetve alvadási folyamatok, a koleszterinszint, a vérnyomás és a cukorbetegség nói jellegzetességeiról. Természetesen pszichoszociális vonatkozásokban is megfigyelhetók különbségek férfiak és nók között. Például a dohányzás károsító hatása nók esetében kifejezettebb. A nók érzékenyebbek a stresszhelyzetek hatására (fóleg kapcsolataikkal összefüggésben), s hajlamosabbak depresszióra.

A kötet harmadik tartalmi súlypontját az elmúlt 20 év pszichokardiológiai intervenciós kutatásai jelentik. Az eddigi eredmények alapján úgy túnik, hogy nók esetében azok a programok a leghatékonyabbak, amelyekben kisebb (<10 fó) csoportokban, szegregáltan csak nók vesznek részt, kognitív módszereket alkalmaznak, és a fó cél a stressz csökkentése.

A kötet fejezetei a nók szív- és érrendszeri egészségének olyan komplex témáit járják körbe, mint a depresszió szociális, kapcsolati vonatkozásai, a gén-környezet interakciók feltételezhető szerepe, valamint a nók kettős munkahelyi és családi - szerepeinek kiegyensúlyozása. A kutatások eredményei remélhetóleg további ösztönzést adnak a terület szakembereinek, hogy olyan differenciált kezelési módszereket dolgozzanak ki, amelyek segítenek megelőzni a legnagyobb népegészségügyi problémát jelentő szívbetegségeket, illetve csökkentsék a nemi vonatkozásokban jelenleg tapasztalható különbségeket az egészségügyi ellátásban.

A kötet címszavakban az alábbi kutatási témákat és eredményeket járja körbe. Epidemiológia és kockázati tényezók. A nók kardiovaszkuláris betegségeinek prevalenciája és incidenciája: pszichoszociális stressz, morbiditás és mortalitás. A nók egészsége és a szocioökonómiai státusz: az élethosszig tartó fejlődés perspektívája. A nók egészsége, munka és családi élet. A koragyermekkori stressz jelentốsége: a nók pszichoszociális kockázati tényezói, különös tekintettel a poszttraumás stressz zavarra. Kórélettani összefüggések: pszichofiziológiai stresszmechanizmusok: kortizol és katecholaminok. Nói nemi hormonok: a menopauza és a nók egészsége. Pszichoneuroimmunológiai folyamatok nók esetében. Neurobiológiai és genetikai mechanizmusok nóknél. Helyreállító és öngyógyító folyamatok: alvásminóség és a nói szervezet regenerálódása. Poszttraumás stressz zavar: korai hatás 
az idegrendszer múködésére és a pszichobiológiai folyamatokra. Légzési mintázatok és vérnyomás-szabályozás nók esetében. Stresszcsökkentô és egészségfejlesztó intervenciók nók részére. Randomizált klinikai vizsgálatok a nók egészségével kapcsolatban. Az életkészségek (kognitív folyamatok és kommunikációs készségek) gyakorlásának hatása a nók egészségére. Eredményes intervenciós módszerek nóbetegek részére: egy kognitív program gyakorlati megvalósításának tapasztalatai különbözó nôi csoportok esetében. A nók kardiovaszkuláris egészségével kapcsolatos elmúlt húsz évet felöleló kutatások összefoglalása.

Összességében elmondható, hogy a kardiológiai pszichoszomatikán belül a nemi különbségek témájának jelentôs kutatása és szakirodalma alakult ki, amelynek tapasztalatai az egész medicinában fontos érvként szolgálnak a nemi különbségek figyelembevétele mellett. Ma már önálló irányzattá vált a "gender medicine", amely a biológiai nemi különbségek mellett a társadalmi nem, a gender jelentóségét is intenzíven vizsgálja az egyes betegségekkel kapcsolatos tényezók között.

A kötet ajánlható a korszerú pszichoszomatika iránt érdeklódó kollégáknak. Elsősorban azoknak, akiket érdekelnek a kardiológiai vonatkozások, akik maguk is kutatják a szívbetegségek pszichoszociális, illetve gender aspektusait, s akik foglalkoznak a pszichológiai segítés lehetóségeivel.

Tiringer István

E-mail: istvan.tiringer@aok.pte.hu

Pamela Emmerling:

\section{Ärztliche Kommunikation}

(Orvosi kommunikáció)

Schattauer, Stuttgart, 2015

263 oldal, 29,99 EUR

ISBN: 978-3-7945-2974-2

A jelen kötet szerzóje pszichoterapeuta és kommunikációs tréner. Hoszszú évek óta elsósorban orvosi kommunikációs kérdésekkel foglalkozik, továbbképzési programokat tart különbözô orvoscsoportoknak. A kötet kommunikációfejlesztô képzéseinek témaköreit foglalja össze; a szerzó írásmódja is megeleveníti a szemináriumok légkörét, párbeszédbe vonja, folyamatos önreflexióra készteti az olvasót.

A kötet tükrözi a szerzó vonzalmát a különbözó kommunikációs elméletekhez. Több mint ötven ilyen alapvetó teóriát és kapcsolódó technikát mutat be, összefogottan, érzékletesen; látszik, hogy már sokat próbálta 
óket, ismeri a hasznukat, korlátaikat, s a különbözó elméletek kapcsolódási pontjait is. ("There is nothing more practical than a good theory" - ez a Kurt Lewin-idézet mottója lehetne a könyonek.) Az elméletek hangsúlya ellenére a kötet szövege egyáltalán nem steril, köszönhetóen a gyógyítás hétköznapjaiból hozott számos példának. Továbbá mindegyik téma tárgyalásához kapcsolódik néhány olvasóknak szóló kérdés, amely a személyes tapasztalatok átgondolására ösztönöz, ezáltal segítve a késóbbi alkalmazást. Az adott téma lezárásaként pedig két képzeletbeli orvos, Dr. No és Dr. Will foglalja össze egy-egy mondatban véleményét - kontra és pro - saját tapasztalatai alapján.

A bevezetô fejezet néhány alaptézist foglal össze, pl. olyanokat, hogy a kommunikáció tanulható; ha sikeres, azzal idôt és pénzt takaríthatunk meg; javítja a betegek együttmúködését; s önmagában is gyógyító eróvel bír.

A 2. fejezet a kommunikáció „nagy" elméleteit tárgyalja, többek között a nálunk is jól ismert szerzóket, mint Satir, Watzlawick, Rogers, Schulz von Tun, s olyanokat is, akiknek elképzelései ma már általánosan ismertek, de nevét már nem igen ismerjük (pl. a verbális és nemverbális kommunikáció viszonyát vizsgáló Merabian-ét). Érdekes volt az erőszakmentes kommunikáció elméletéról olvasni, egy Rosenberg nevú szerzót idézve.

A 3. fejezet a páciensek jobb megértését segítő stratégiákat tárgyal. Megismerteti az olvasót egyszerú, plauzibilis személyiségtipológiákkal, jó leírást ad a tranzakcióanalízis alapjairól, az aktív meghallgatás jelentőségéról, a személyközi észlelés jellegzetes torzításairól, és a metakommunikációban rejlô lehetóségekról.

A 4. fejezet az orvosokat veszi nagyító alá, elsósorban azt vizsgálva, hogy milyen eróforrások segíthetik a betegekkel történó kapcsolat hatékonyságát, s növelhetik a gyógyítók elégedettségét munkájukkal. Az alfejezetek címei is mutatják, hogy a szerzó egyfajta tükröt tart az olvasóknak: a szokások hatalmáról, személyiségünk vakfoltjairól, motivációkról és az azokkal kapcsolatos diszfunkcionális attitúdökról olvashatunk. A személyes átgondolást önkitöltố kérdốivek is támogatják. Ezen túl támpontokat kapunk még a kapcsolati szerepajánlatok értelmezéséhez és a konfliktusok kezeléséhez. A szerző külön kitér a visszajelzések fontosságára.

Az 5. fejezet a teamen belüli kommunikációhoz kapcsolódó témákat járja körbe. Talán ennél a fejezetnél kevésbé volt jól követhető a témák kiválasztása. Miért itt tárgyal a szerzó olyan általános témákat, mint a kérdéstípusok, a rugalmasság stratégiája, a destruktív kommunikáció jellemzói vagy a meggyőzés módszerei? A fejezet ívének bizonytalansága azonban nem von le az egyes témák tárgyalásának értékéból.

A 6. fejezetet „haladóknak” szánja a szerzô, olyan komplexebb kommunikációs helyzeteket mutat be, mint a közös döntéshozatal, a rossz hírek 
közlésének SPIKES modellje, a mediáció alapjai, a humor, a metaforák, és a gyógyítást, megküzdést segító narratívák megfelelô használata.

A záró fejezet a szerzó hitvallásának is tekinthetó, amiben arról ír, mi adhat reményt az orvos-beteg kapcsolatnak egy olyan korszakban, amelynek változási tendenciái egyre inkább háttérbe szorítják a közvetlen jelenléten alapuló, spontán alakuló, de annál pontosabb és személyesebb kölcsönös megértést.

Az érdeklődó olvasó további tájékozódását segíti a könyv végén található irodalomjegyzék (kb. 150, elsósorban német nyelvú forrás), valamint a használatot, áttekintést segítő tárgymutató.

A kötet elolvasása nagyon inspiráló, jó háttérként használható mindenkinek, akit érdekelnek az orvosi kommunikáció kérdései, és az orvosi pszichoterápia általánosan használható alaptechnikái. Különösen, ha saját maga is foglalkozik az orvosi kommunikáció oktatásával és fejlesztésével.

Tiringer István

E-mail: istvan.tiringer@aok.pte.hu 